PENANGGUNG JAWAB

Dekan Fakultas Ilmu Tarbiyah dan Keguruan

REVIEWER

Ani Cahyadi

Universitas Islam Negeri Antasari Banjarmasin, Indonesia

Imam Rofiki

Universitas Islam Negeri Maulana Malik Ibrahim Malang, Indonesia

Nuril Mufidah

Universitas Islam Negeri Maulana Malik Ibrahim Malang, Indonesia

Nuri Wuryandani

Universitas Negeri Yogyakarta, Indonesia

Muhammad Walid

Universitas Islam Negeri Maulana Malik Ibrahim Malang, Indonesia

Wahid Murni

Universitas Islam Negeri Maulana Malik Ibrahim Malang, Indonesia

EDITOR IN CHIEF

M. Irfan Islamy

Universitas Islam Negeri Maulana Malik Ibrahim Malang, Indonesia

SECTION EDITOR

Abdul Fattah

Universitas Islam Negeri Maulana Malik Ibrahim Malang, Indonesia

Galih Puji Mulyanto

Universitas Islam Negeri Maulana Malik Ibrahim Malang, Indonesia

Dewi Nur Suci

Sekolah Tinggi Agama Islam Kediri, Indonesia

Dwi Sulistiani

Universitas Islam Negeri Maulana Malik Ibrahim Malang, Indonesia

LAYOUT EDITOR

Rendi Setyo Marandi

Universitas Islam Negeri Maulana Malik Ibrahim Malang, Indonesia 
ii | P a g e

PEDOMAN TRANSLITERASI

\begin{tabular}{|c|c|c|c|}
\hline Arab & Latin & Arab & Latin \\
\hline 1 & $a$ & ض & $\mathrm{dh}$ \\
\hline ب & $\mathrm{b}$ & $b$ & th \\
\hline ت & $t$ & b & zh \\
\hline$ث$ & ts & $\varepsilon$ & 1 \\
\hline ج & $\mathrm{j}$ & $\dot{\varepsilon}$ & gh \\
\hline$\tau$ & $\mathrm{h}$ & ف & $\mathrm{f}$ \\
\hline$\dot{\tau}$ & kh & ق & $q$ \\
\hline د & d & ك & $\mathrm{k}$ \\
\hline ذذ & $\mathrm{dz}$ & J & 1 \\
\hline נ & $r$ & م & $\mathrm{m}$ \\
\hline j & $\mathrm{Z}$ & ن & $\mathrm{n}$ \\
\hline س & S & 9 & $\mathrm{~W}$ \\
\hline ش & sy & هـ & $\mathrm{h}$ \\
\hline ص & sh & ى & $\mathrm{y}$ \\
\hline
\end{tabular}


DAFTAR ISI

i

PENANGGUNG JAWAB

i

REVIEWER

i

EDITOR IN CHIEF

i

SECTION EDITOR

i

LAYOUT EDITOR

ii

PEDOMAN TRANSLITERASI

iii

DAFTAR ISI

01-12

Pembelajaran Bahasa Arab di MIN 13 Kabupaten Banjar Kalimantan Selatan

Mahmudah

Universitas Islam Negeri Antasari Banjarmasin, Indonesia

13-23

Keefektifan Model Make A Match dalam Pembelajaran Matematika Siswa Kelas VI

Sekolah Dasar di Kecamatan Marioriwawo

Andi Kaharuddin

Universitas Lakidende Unaaha, Indonesia

24-39

Konsepsi Penerapan Keterampilan Proses Sains (KPS) dan Sikap Ilmiah Dalam Desain Pengembangan Modul Panduan Eksperimen Ipa SD/MI

Ida Fiteriani ${ }^{1}$ dan Baharuddin ${ }^{2}$

1,2Universitas Islam Negeri Raden Intan Lampung, Indonesia

40-45

Pengembangan Multimedia Pembelajaran Interaktif Materi Pokok Sistem Tata Surya Untuk Siswa Kelas VI SD

Vannisa Aviana Melindaㄹ, Dimas Sambung'2, Dian Eka Aprilia Fitria Ningrum³ ${ }^{3}$ Imroatul Hayyu Erfantinni ${ }^{4}$, Roiyan One Febriani ${ }^{5}$

1,2,3,4,5Universitas Islam Negeri Antasari Banjarmasin Indonesia, Indonesia

46-52

Pengembangan Media Pembelajaran Pop-Up Berbasis Sains Kelompok B RA Raden Fatah Podorejo

Dessy Putri Wahyuningtyas ${ }^{1}$, Faizatun Na'fiah

1,2Universitas Islam Negeri Maulana Malik Ibrahim Malang, Indonesia

PEDOMAN PENULISAN

UCAPAN TERIMAKASIH

Vol. 11 No. 1, Desember 2018

Madrasah homepage: http://ejournal.uin-malang.ac.id/index.php/madrasah/index 


\title{
MADRASAH
}

Jurnal Pendidikan dan Pembelajaran Dasar

p ISSN: 1979-5599 | e ISSN: 2502-194X

Page | 1

\section{PEMBELAJARAN BAHASA ARAB \\ DI MIN 13 KABUPATEN BANJAR KALIMANTAN SELATAN}

\author{
Mahmudah \\ Universitas Islam Negeri (UIN) Antasari Banjarmasin, Indonesia \\ Mahmudah.syifa25@gmail.com
}

DOI: $10.18860 /$ madrasah.v11i1.5711

Abstrak. Tujuan penelitian ini untuk mendeskripsikan proses kegiatan belajar dan mengajar Bahasa Arab di MIN 13 Banjar dan mengetahui ruang lingkup pembelajaran Bahasa Arab di MIN 13 Banjar. Penelitian ini merupakan penelitian deskriptif kualitatif. Pengambilan data menggunakan beberapa teknik pengumpulan data, yaitu: observasi untuk mengamati proses pembelajaran pasa saat proses belajar dan mengajar Bahasa Arab yang berlangsung di kelas, dokumentasi untuk menganalisis ruang lingkup materi Bahasa Arab, dan wawancara dengan guru Mata Pelajaran Bahasa Arab untuk menggali data proses pembelajaran. Analisis data dalam penelitian ini dilakukan dalam tiga tahap, yaitu reduksi data, penyajian data, dan penarikan kesimpulan.Berdasarkan penelitian yang dilakukan maka didapatkan hasil sebagai berikut: proses pembelajaran menyangkut perencanaan proses: dilakukan dengan pembuatan silabus dan rencana pelaksanaan pembelajaran (RPP) dan pembelajaran diusahakan sesuai dengan apa yang telah direncanakan sehingga pembelajaran dapat berjalan sistematis. Ruang lingkup pelajaran Bahasa Arab di Madrasah Ibtidaiyah meliputi beberapa tema yaitu: perkenalan, peralatan sekolah, profesi, alamat, keluarga, anggota btubuh, di rumah, di kebun, di sekolah, di perpustakaan, di kantin, jam, kegiatan sehari hari, pekerjaan, rumah, dan rekreasi.

Kata Kunci. Pembelajaran; Bahasa Arab; Madrasah Ibtidaiyah

Abstract. The purpose of this study was to explain the process of learning and teaching Arabic at MIN 13 Banjar and knowing the scope of learning Arabic at MIN 13 Banjar. This study is a qualitative desktiptif study. To collect data, researchers used several data collection techniques, namely, observation to observe the learning process during the process of learning and teaching Arabic which took place in the classroom, documentation for analyzing the scope of Arabic Language material, and interviews with Arabic Subject teachers to explore data. learning process. Analysis of the data in this study was carried out in three stages, namely data reduction, data presentation, and conclusion. Based on the research conducted, the following results were obtained: the learning process involved process planning: carried out by making syllabus and learning implementation plans (RPP) and learning arranged according to what has been planned so that learning can run systematically. The scope of Arabic Language lessons at Madrasah Ibtidaiyah includes a number of themes, namely: introduction, school equipment, profession, address, family, body members, at home, in the garden, at school, in the library, in the canteen, hours, daily activities, work home, and recreation

Keywords. Learning; Arabic Language; Madrasah Ibtidaiyah

\begin{tabular}{ll|l}
\hline Received : 28 Oktober 2018 & Approved : 05 Desember 2018
\end{tabular}

$\begin{array}{lll}\text { Revised }: 10 \text { Desember } 2018 & \text { Published :12 Desember } 2018\end{array}$

Copyright $@$ Madrasah Jurnal Pendidikan dan Pembelajaran Dasar. All Right Reserved.

This is an open-access article under the CC BY-NC-ND license

(http:/ / creativecommons.org/licenses/by-nc-nd/4.0/).

Correspondence Address: mahmudah.syifa25@gmail.com 


\section{A. PENDAHULUAN}

Pada dasarnya pendidikan dapat didefinisikan sebagai kegiatan sadar dan terencana untuk proses belajar dan pembelajaran agar peserta didik secara aktif mengembangkan potensi dirinya serta memiliki kekuatan spiritual keagamaan, pengendalian diri, kepribadian, kecerdasan, akhlak mulia, serta keterampilan yang diperlukan dirinya dan masyarakat (UU No. 20 tahun 2003). Sekolah sebagai Lembaga formal sebagai wadah dalam rangkamencapaian tujuan pendidikan. Melalui sekolah peserta didik belajar berbagaimacam hal maka akan menunjukkan adanyaperubahan yang sifatnya lebih baik, dengan demikian pada tahap akhir didapat keterampilan,kecakapan dan pengetahuan baru.

Pendidikan tentu tidak akan lepas dari proseskegiatan belajar mengajar, yang merupakan salah satu kegiatan inti pendidikan formal di sekolah. Dalam pembelajaran terjadi interaksi antar guru, materi pelajaran, dan peserta didik. Interaksi antar komponen tersebut memerlukan sarana dan prasarana seperti metode, media, dan penataan lingkungan sebagai tempat belajar, sehingga terbentuk situasi pembelajaran yang bisa mencapai tujuan yang telah direncanakan sebelumnya (Ali, 2007: 4).

Sardiman (2010:146) mengemukakan bahwa hubungan guru dengan peserta didik di dalam proses belajar mengajar salah satu unsur penentu hasil pembelajaran. Ini berarti inti dari pendidikan, khususnya pendidikan formal, adalah proses belajar mengajar di sekolah yang telah dirancang sedemikian rupa sehingga dapat menghasilkan lulusan yang berkualitas. Rancangan proses pendidikan memiliki posisi yang strategis karena seluruh kegiatan dalam proses belajar mengajar yang harus dilakukan terkandung didalamnya. Keseluruhan rancangan yang digunakan sebagai panduan dalam kegiatan pembelajaran diintegrasikan dalam sebuah kurikulum, yaitu seperangkat rancangan yang didalamnya terdapat pengaturan mengenai tujuan pembelajaran, materi pembelajaran, serta cara yang digunakan sebagai acuan untuk melaksanakan kegiatan pembelajaran (UU No 20 Tahun 2013).

Menurut Makmun dalam (Iskandar, 2009:100) proses kegiatan belajar mengajar adalah semua rangkaian proses interaksi peserta didik dengan guru guna tercapainya tujuan. Coley (1986) di dalam (Sagala, 2003:61) Pembelajaran merupakan proses yang mana lingkungan seseorang secara sengaja dikelola untuk memungkinkan ikut serta dalam tingkah laku tertentu dalam keadaan khusus atau menghasilkan respon terhadap keadaan tertentu. Pembelajaran mempunyai dua karekteristik, pertama, dalam proses pembelajaran membangun suasana dialogis dengan proses tanya jawab dan diskusi yang dilakukan secara berkesinambungan untuk memperbaiki serta meningkatkan kemampuan berpikir peserta didik. Kemampuan berfikir itu dapat membantu peserta didik untuk memperoleh pengetahuan yang mereka bangun sendiri, Kedua dalam proses pembelajaran harus melibatkan proses berfikir. (Sagala, 2003:63).

Peratuan Pemerintah No.19 Tahun 2005 Bab 1 Pasal 1 Ayat 6 tentang Standar Nasional Pendidikan dikataan standar proses bisa juga diartikan suatu bentuk teknis yang merupakan pedoman serta kriteria yang telah dibuat secara terencana dalam kegiatan pebelajar mengajar pada satu satuan pendidikan guna mencapai standar kompetensi lulusan. Standar Proses sendiri terdiri dari empat aspek yaitu perencanaan proses kegiatan pembelajaran, pelaksanaan proses kegiatan pembelajaran, penilaian hasil kegiatan pembelajaran, serta pengawasan proses kegiatan pembelajaran. 


\section{MADRASAH}

Jurnal Pendidikan dan Pembelajaran Dasar

p ISSN: 1979-5599 | e ISSN: 2502-194X

Page $\mid 3$

Kurikulum dan pembelajaran merupakan dua hal yang tidak bisa terpisahkan walaupun keduanya mempunyai posisi yang tidak sama dalam pendidikan. Tahun 2013 pemerintah mulai mengimplementasikan kurikulum baru yaitu kurikulum 2013 diberlakukan secara bertahap pada sistem pendidikan nasional. Kurikulum 2013 menekankan keseimbangan berbagai kompetensi yaitu sikap, pengetahuan, dan keterampilan. Kurikulum 2013 meerupakan proses pembelajaran yang tidak hanya terfokus pada kompetensi pengetahuan saja, akan tetapi juga menekankan sikap dan keterampilan melalui proses mengamati, menanya, mengumpulkan informasi, mengolah informasi, dan menginformasikan yang lebih dikenal dengan scientific approach.

Kurikulum 2013 yang telah diterapkan oleh pemerintah saat ini, tentu saja juga membawa perubahan pada mata pelajaran Bahasa Arab. Baik dari segi proses maupun ruang lingkup materi Bahasa Arab nya. Pembelajaran bahasa Arab adalah kegiatan transfer ilmu pengetahuan oleh guru kepada peserta didik dengan menggunakan bahasa Arab, yang mempunyai bertujuan peserta didik bisa lebih memahami dan mampu menguasai bahasa Arab dan mengembangkannya (Anshor, 2009:6). Kegiatan Belajar Mengajar (KBM) dirancang sedemikian rupa dengan tetap mengikuti prinsip belajar mengajar dan prinsip motivasi dalam belajar bahasa Arab.

Pembelajaran bahasa Arab mempunyai tiga prinsip yang perlu diperhatikan (Abdul Hamid, 2010:166), yaitu: 1) Prinsip perencanaan, sebelum melaksanakan kegiatan pembelajaran Bahasa Arab, terlebih dahulu guru harus menyiapkan materi ajar yang akan diberikan kepada peserta didik (Azhar Arsyad, 2004:28) 2) Prinsip pelaksanaan, beberapa hal yang harus menjadi perhatian guru Bahasa Arab yaitu tahapan kegiatan dalam penyampaian materi ajar kepada peserta didik. 3) Prinsip evaluasi, setelah melaksanakan kegiatan pembelajaran, diperlukan melaksanakan kegiatan evaluasi yang bertujuan mengetahui sejauh mana tingkat keberhasilan yang telah dicapai dari kegiatan proses pembelajaran (Mulyasa, 2006:255)

Pembelajaran Bahasa Arab yang diajarkan di Madrasah Ibtidaiyah pun tentu memiliki ruang lingkup pembahasan tersendiri yang sesuai dengan tingkatannya. Materi Bahasa Arab di Madrasah Ibtidaiyah memiliki ruang lingkup yang berbentuk tema-tema, yaitu : tentang perkenalan/ta'aruf, peralatan sekolah, profesi, alamat, keluarga, anggota tubuh, di rumah, di kebun, di sekolah, di laboratorium, di perpustakaan, di kantin, jam, kegiatan sehari hari, rumah, dan rekreasi. Semua tema itu merupakan hal yang berada dilingkungan peserta didik dan mereka juga bisa lebihmengetahui konteks nya. Hal tersebut juga mempunyai kesamaan dengan karakteristik Bahasa Arab pada jenjang sekolah dasar yang mana dititik beratkan pada empat kecakapan yaitu menyimak, berbicara, membaca dan menulis yang merupakan landasan berbahasa.

Pada hakikatnya, Pembelajaran Bahasa Arab di Madrasah Ibtidaiyah yang selama ini sama sama diketahui sangat terfokus pada 4 aspek keterampilan, sehingga pada kurikulum sebelumnya kompetensi yang harus dicapai peserta didik mencakup 4 aspek keterampilan berbahasa yakni menyimak, membaca, mengucapkan dan menulis. Sedangkan pada kurikulum 2013 ini pembelajaran bahasa, termasuk Bahasa Arab di usahakan untuk berbasis teks dan fungsi teks. Oleh karena itu pembelajaran dan ruang 
lingkup pembelajaran tentu berbeda dengan pembelajaran Bahasa Arab pada kurikulum sebelumnya.

Berdasarkan latar belakang tersebut, penelitian ini difokuskan untuk mendapatkan gambaran lebih detail mengenai proses pembelajaran dan ruang lingkup pembelajaran Bahasa Arab. Penelitian ini dilakukan pada Madrasah Ibtidaiyah Negeri 13 Banjar yang telah menerapkan secara utuh pembelajaran berbasis kurikulum 2013. Hasil penelitian ini juga diharapkan memberikan manfaat bagi guru Bahasa Arab di MIN 13 Banjar dalam meningkatkan kemampuan peserta didik dalam berbahasa Arab.

\section{B. METODE PENELITIAN}

Penelitian ini merupakan penelitian desktiptif kualitatif. Penelitian ini dilakukan di Madrasah Ibtidaiyah Negeri 13 Banjar yang terletak di Kabupaten Banjar Provinsi Kalimantan Selatan. Guru pengajar bahasa Arab di MIN 13 Banjar merupakan subjek dalam penelitian. Peneliti menggunakan beberapa teknik pengumpulan data, yaitu, observasi, dokumentasi dan wawancara. Observasi langsung dilakukan ditempat penelitian yaitu MIN 13 Banjar untuk mengamati proses pembelajaran yang sedang berlangsung. Metode dokumentasi dilakukan untuk memperoleh data pendukung yang digunakan sebagai dasar untuk bahan menganalisis proses serta ruang lingkup pembelajaran Bahasa Arab. Kemudian dokumen pendukung tersebut dijadikan peneliti sebagai bahan wawancara untuk menggali informasi lebih dalam tentang proses dan ruang lingkup tersebut. Budiyono (2003:52) mengatakan wawancara merupakan tekhnik pengumpulan data yang bisa dilakukan dengan percakapan antara peneliti dengan responden. Wawancara dalam penelitian ini dilakukan terhadap 1 guru Bahasa Arab, dipilih 1 guru karena memang pada sekolah ini hanya memiliki 1 guru Bahasa Arab. Data utama penelitian ini semua informasi tentang proses kegiatan pembelajaran dan ruang lingkup pembelajaran Bahasa Arab itu sendiri. Langkah dalam analisis data dilakukan dalam tiga tahap, yaitu reduksi data, penyajian data, dan penarikan kesimpulan (Milles \& Huberman, 1992:16). Reduksi data dalam penelitian ini dilakukan dengan memilih data yang telah diperoleh melalui observasi dan wawancara. Penyajian data dalam penelitian ini merupakan hasil observasi, hasil wawancara, dan hasil validasi data.

\section{HASIL DAN PEMBAHASAN}

Berdasarkan penelitian yang dilakukan maka didapatkan hasil sebagai berikut:

\section{Proses Pembelajaran Bahasa Arab di MIN 13 Banjar}

Tiga prinsip yang harus diperhatikan guru dalam pembelajaran Bahasa Arab yaitu: prinsip perencanaan pembelajaran, prinsip pelaksanaan pembelajaran, dan prinsip evaluasi hasil belajar.

a. Perencanaan Proses Pembelajaran

1) Silabus

Madrasah Ibtidaiyah Negeri 13 Banjar merupakan sekolah yang juga menggunakan kurikulum 2013 sebagai landasan kurikulumnya. Silabus adalah seperangkat rancangan dan aturan yang berkaitan tentang kegiatan pembelajaran, pengelolaan kelas, dan penilaian hasil belajar. Silabus yang terdapat pada sekolah ini sama halnya dengan silabus yang digunakan pada sekolah lain, di dalamnya termuat dari kompetensi inti, kompetensi dasar, mata pelajaran, materi pokok pembelajaran, 


\section{MADRASAH}

Jurnal Pendidikan dan Pembelajaran Dasar

p ISSN: 1979-5599 | e ISSN: 2502-194X

Page | 5

evaluasi, alokasi waktu, dan sumber belajar.Sedangkan pembagian materi pada setiap jam pelajaran disesuaikan dengan buku dan materi yang telah ditetapkan.

Silabus harus berisikan kompotensi pokok seperti berikut ini:

a) Melalui kegiatan pembelajaran kompetensi ditanamkan kepada peserta didik

b) Kegiatan pembelajaran yang dilakukan bertujuan menanamkan/ membentuk kompetensi tersebut

c) Usaha yang dilakukan guru bertujuan mengetahui kompetensi tersebut sudah dimiliki oleh peserta didik

Silabus merupakan pedoman sumber pokok dalam pengembangan program pembelajaran lebih lanjut,pembuatan rencana pembelajaran, dalam hal mengelolaproses kegiatan pembelajaran, dan pengembangan evaluasi. Pada dasarnya pembuatan silabus dapat dibuat sendiri oleh guru jika guru tersebut bisa mengenali karakteristik peserta didik di kelasnya serta kondisi lingkungan. Apabila guru mata pelajaran belum bisa pengembangan silabus, pihak sekolah membentuk kelompok kerja guru untuk mengembangkan silabus yang akan digunakan oleh guru.

Pada sekolah ini, pembuatan silabus dilakukan melalui 2 tahap. Tahap pertama silabus dibuat oleh wakil kepala sekolah bidang kurikulum yang mengadobsi modifikasi dari silabus berdasarkan KI dan KD yang memang telah ditetapkan oleh kementrian sebagai standar kelulusan peserta didik.Keseluruhan komponen silabus diperhatikan kembali dan di perbaiki hingga dapat mengakomodirperbedaan peserta didik, kondisi pendidik, serta dinamika perubahan yang telah terjadi di sekolah serta tuntutan masyarakat.

Kemudian silabus yang telah dibuat diserahkan kepada guru mata pelajaran bahasa Arab untuk dimodifikasi kembali berdasarkan karakteristik peserta didik sehingga dapat dimuat kegiatan pembelajaran secara garis besar pada silabus. Pada tahap ini guru bahasa Arab memeriksa kembali beberapa hal agar silabus dapat digunakan dengan efektif, hal yang diperhatikan antara lain:

a) Keseluruhan indikator pembelajaran, materi pokok pembelajaran, pengalaman belajar mengajar, sumber belajar, dan sistem evaluasi mampu menunjang tercapainya kompetensi dasar dan kompetensi inti.

b) Keseluruhan indicator pembelajaran, materi pokok pembelajaran, pengalaman belajar mengajar, sumber belajar, dan sistem evaluasi juga memperhatikan perkembangan ilmu pengetahuan dan teknologi dalam kehidupan serta tetap harus memperhatikan karakteristik peserta didik.

c) Keseluruhan komponen silabus dapat memenuhi kebutuhan dari setiap perbedaan peserta didik, kondisi pendidik, serta perubahan yang bisa terjadi di sekolah maupun tuntutan masyarakat.

d) Keseluruhan komponen silabus meliputi ranahkognitif, afektif, psikomotor.

Pada MIN 13 Banjar ini, silabus disusun pertahun, sehingga pengembangan silabus yang dilakukan oleh sekolah ini pun hanya berlangsung satu tahun sekali. Silabus mata pelajaran bahasa Arab ini disusun dengan memuat seluruh alokasi waktu yang disediakan untuk mata pelajaran selama satu tahun penuh akan tetapi dengan tetap memperhatikan alokasi waktu yang akan disediakan untuk kegiatan belajar mengajar selama satu semester dan jumlah satu tahun.

2) Rencana Pelaksanaan Pembelajaran (RPP) 
Pembuatan rencana pelaksanaan pembelajaran (RPP) pada MIN 13 Banjar juga melalui 2 tahap pembuatan, yaitu dibuat secara umum berdasarkan kompetensi kompetensi yang telah ditetapkan secara nasional, pembuatan tahap pertama ini dilakukan oleh wakil kepala sekolah bidang kurikulum. RPP pada tahap ini dibuat menurut standar pembuatan RPP yaitu meliputi: identitas mata pelajaran (kelas, mata pelajaran, materi pokok pembelajaran, dan alokasi waktu yang disediakan), tujuan dan indikator pembelajaran, pelaksanaan kegiatan pembelajaran secara umum yang berisi Apersepsi, kegiatan inti, dan penutup.

Hal tersebut diatas telah disesuaikan dengan Peraturan Pemerintah Nomor 19 Tahun 2005 tentang standarpembuatan RPP, yaitu dalam membuat RPP setidaknya paling sedikit memuat tujuan/ indikator pembelajaran, materi pokok pembelajaran, metode / media pembelajaran, strategi pembelajaran, sumberbelajar, dan evaluasi. RPP adalah rencana kegiatan proses belajar mengajar dengan tatap muka yang dibuat untuk satu pertemuan atau lebih (Suyono dan Hariyanto, 2015:257).

Setelah pada tahap pembuatan oleh wakil kepala sekolah bidang kurikulum, RPP di lengkapi oleh guru bahasa Arab kembali. Guru akan menyesuaikan dengan karakteristik peserta didik dan lingkungannya, serta melengkapi RPP agar mampu menjadi pedoman yang baik saat pembelajaran. Pada tahap ini guru memperjelas materi pelajaran, pendekatan pembelajaran, strategi dan metode pembelajaran, dan membuat penilaian yang lebih spesifik.

b. Pelaksanaan Pembelajaran Bahasa Arab

1) Persyaratan dalam Pelaksanaan Proses Kegiatan Pembelajaran. Peserta didik pada MIN 13 Banjar rata rata berjumlah 20 orang perkelasnya, dan alokasi waktu setiap tatap muka yaitu 2x35 menit. Buku paket yang digunakan pada MIN 13 Banjar ini adalah buku kurikulum 2013 dengan pendekatan saintifik yang di keluarkan oleh Kementerian Agama Republik Indonesia dan diterbitkan oleh Direktorat Pendidikan Madrasah dan Direktorat Jenderal Pendidikan Islam. Buku pelajaran didapat peserta didik dengan sistem dipinjamkan perpustakaan sekolah untuk setiap peserta didik, sehingga semua peserta didik mendapatkan buku tanpa harus membelinya. Hal tersebut sesuai dengan persyaratan pelaksanaan prosespembelajaran yang ditetapkan pada PERMEN Pendidikan Nasioanal Dan Kebudayaan Republik Indonesia Nomor 65 Tahun 2013 Tentang Standar Proses Pendidikan Dasar Dan Menengah, telah dijelaskan bahwa persyaratan pelaksanaan proses kegiatan pembelajaran pada tiap tingkatan peserta didik. Bagi anak SD/MI di dalam kelas jumlahnya paling sedikit 20 orang dan paling banyak 28 orang, waktu yang disediakan setiap tatap muka selama 35 menit. Buku paket pelajaranatau sumber belajar juga harus disesuaikan dengan keperluan peserta didik.

2) Pelaksanaan Belajar Mengajar. Pelaksanaan kegiatan belajar dan mengajar merupakan pelaksanaan dari RPP, terdiri dari Apersepsi, kegiatan inti, dan penutup, berikut ini beberapa tahap yang dilakasanakan padakegiatan belajar dan mengajar Bahasa Arab di MIN 13 Banjar ini:

a) Kegiatan Apersepsi. Pada awal pembelajaran, guru berusaha semaksimal mungkin untuk menjalankannya sesuai dengan RPP yang telah dibuat sebelumnya. Pembelajaran diawali dengan berdo'a bersama menurut agama dan keyakinan masing-masing, dilanjutkan dengan mengonfirmasi tentang kehadiran peserta didik. Lalu guru menyiapkan fisik dan psikis anak dalam 


\section{MADRASAH}

Jurnal Pendidikan dan Pembelajaran Dasar

p ISSN: 1979-5599 | e ISSN: 2502-194X

Page | 7

mengikuti kegiatan belajar mengajar dengan mengajaknya bernyanyi dengan lagu berisi pelajaran bahasa Arab yang telah dipelajari sebelumnya serta menyapa anak. Selanjutnya guru melakukan apersepsi untuk mengetahui pengetahuan awal dan ingatan peserta didik tentang materi sebelumnya. Setelah itu guru menyampaikan tujuan pembelajaran yang akan dicapai. Kegiatan pendahuluan yang dilaksanakan guru bahasa Arab di MIN 13 Banjar ini sesuai dengan PERMEN Pendidikan Nasional Dan Kebudayaan Republik Indonesia Nomor 65 Tahun 2013 Tentang Standar Proses Pendidikan Dasar dan Menengah, Bab IV dalam hal pelaksanaan kegiatan belajar siswa. Dijelaskan bahwa kegiatan apersepsi ada beberapa hal yang harus menjadi perhatian guru diantara nya adalah; mempersiapkan psikis dan fisik peerta didik untuk mengikuti proses kegiatan belajar dan mengajar serta memberikan motivasi untuk belajar secara kontekstual yang sudah sesuai materi yang akan diajarkan. Guru memberikan beberapa pertanyaan untuk mengkaitkan pengetahuan sebelumnya dengan materi yang akan dipelajari, kemudian guru memberitahu tujuan pembelajaran atau kompetensi dasar yang akan dicapai pada kegiatan belajar mengajar.

b) Kegiatan Inti. Model, metode, dan media pembelajaran serta sumber belajar yang digunakan pada kegiatan inti harus sesuai dengankarakteristik peserta didik serta materi yang akan disampaikan yang tahap tahapnya telah tertulis pada RPP, guru berusaha melakukan kegiatan inti seperti yang telah terencana. Guru menggunakan strategi, media, dan sumber belajar bervariasi tergantung dengan materi yang diajarkan. Kegiatan inti juga diusahakan untuk mengembangkan potensi peserta didik dalam 3 ranah, yaitu sikap, pengetahuan, dan keterampilan dalam berbahasa Arab. Kegiatan inti sudah diatur pada PERMEN Pendidikan Nasional Dan Kebudayaan Republik Indonesia No 65 / 2013, yang menjelaskan bahwa dalam kegiatan inti model, metode, dan media pembelajaran serta sumber belajar harus disesuaikan dkarakteristik pesertadidik dan materi yang akan disampaikan (Suyono dan Hariyanto, 2015: 260-261).

c) Kegiatan Penutup. Guru Bersama peserta didik menyimpulkan/merangkum kegiatan belajar mengajar yang telah dilakukan, lalu guru melakukan diskusi tentang materi yang telah dipelajari yang bertujuan untuk menngetahu tercapianya tujuan. Selanjutnya peserta didik diberi kesempatan untuk memberikan pendapatnya tentang kegiatan belajar dan mengajar yang telah dilaksanakan. Guru melakukan penilaian yang berdasarkan indikator pencapaian yang ingin dicapai. Pada akhir pelajaran guru mengajak semua peserta didik berdo'a. Kegiatan penutup sudah sesuai dengan yang tercantum pada PERMEN Pendidikan Nasional Dan Kebudayaan Republik Indonesia Nomor 65 Tahun 2013, dalam kegiatan penutup guru dan peserta didik secara bersama-sama melaksanakan beberapa refleksi seperti umpan balik dari guru terhadap proses dan hasil belajar yang dilakukan baik secara individual maupun kelompok guru junga memberitahukan rencana kegiatan belajar mengajar poada pertemuan selanjutnya. 


\section{Ruang Lingkup Pembelajaran Bahasa Arab}

Pembelajaran yang diajarkan di Madrasah Ibtidaiyah pun tentu memiliki ruang lingkup sendiri yang sesuai dengan tingkatannya. Meliputi tema tentang perkenalan, peralatan sekolah, pekerjaan, alamat, keluarga, anggota badan, di rumah, di kebun, di sekolah, di perpustakaan, di kantin, jam, kegiatan sehari hari, pekerjaan, rumah, dan rekreasi. Yang semua tema itu merupakan hal hal yang ada disekitar mereka dan mereka ketahui konteks nya. Ini juga sesuai dengan karakteristik Bahasa Arab pada jenjang sekolah dasar yang dititik beratkan pada kecakapan menyimak dan berbicara yang merupakan landasan berbahasa. Ruang lingkup tersebut dapat dirincikan sebagai berikut:

a. Materi yang di ajarkan:

1) Kelas 1

a) Semester 1

Tema tentang kosakata kegiatan mengabsen, berkenalan, peralatan tulis, dan peralatan sekolah dengan kompetensi dasar mampu menyimak, membaca, menulis, dan berbicara tentang

$$
\text { ,عَمَلُ الكَشْفَ , الأدوات المدرسية,الأدوات الكتابية ,التعارف }
$$

b) Semester 2

Tema tentang kosakata mengenal angka dari 1-10, nama nama hari, buahbuahan, dan warna-warna dengan kompetensi dasar mampu menyimak, membaca, menulis, dan berbicara tentang

$$
\text { العدد 1 -. - أسماء الأيام , بعض أسماء الفواكها, بعض الألوان. }
$$

2) Kelas 2

a) Semester 1

Tema tentang kosakata profesi yang ada di sekolah, seragam sekolah, minuman dan makanan yang ada dikantin, dan mushala sekolah, dengan kompetensi dasar mampu menyimak, membaca, menulis dan berbicara tentang:

$$
\text { المشروباتوالماكولاتفيالمقصف,مصلى المدرسة, الزيالمدرسيّ ,أفراد المدرسة }
$$

b) Semester 2

Tema tentang kosakata alat transportasi, lalu lintas, dan peralatan dirumah dengan kompetensi dasar mampu menyimak, membaca, menulis, dan berbicara tentang:

3) Kelas 3

$$
\text { آلاتالمواصلات,البيتوما فياء,إشـارةالمرور }
$$

a) Semester 1

Tema tentang kosakata nama pelajaran, kosakata sholat 5 waktu, anggota wudhu, dan nama penyakit dengan kompetensi dasar mampu menyimak, membaca, menulis, dan berbicara tentang:

$$
\text { أسماء الدرس,الصلوات الخمس, أعضياء الوضوء , أسماء الأمراض }
$$

b) Semester 2

Tema tentang kosakata anggota keluarga, kondisi taman, dan nama binatang, dengan kompetensi dasar mampu menyimak, membaca, menulis, dan berbicara tentang: 


\section{MADRASAH}

Jurnal Pendidikan dan Pembelajaran Dasar

4) Kelas 4

a) Semester 1

Tema tentang perkenalan, alat-alat sekolah dan profesi dengan kompetensi dasar mampu menyimak, membaca, menulis dan berbicara tentang

b) Semester 2

المهنة، الأدوات المدرسية، التعارف

Tema tentang alamat, keluargaku dan anggota tubuh dengan kompetensi dasar mampu menyimak, membaca, menulis dan berbicara tentang

5) Kelas 5

أعضاء الإنسان، أسرتي، العنوان

a) Semester 1

Tema tentang lingkungan rumahdengan kompetensi dasar mampu menyimak, membaca, menulis dan berbicara tentang

b) Semester 2

في البيت، في الحديقة + الألوان

Tema tentang lingkungan sekolah dengan kompetensi dasar mampu menyimak, membaca, menulis dan berbicara tentang

6) Kelas 6

في المدرسة، في العمل، في المكتبة، في المقصف

a) Semester 1

Tema tentang kegiatan sehari-hari dengan kompetensi dasar mampu menyimak, membaca, menulis dan berbicara tentang

b) Semester 2

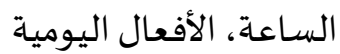

Tema tentang kegiatan yang telah dilakukandengan kompetensi dasar mampu menyimak, membaca, menulis dan berbicara tentang

$$
\text { الواجب المنتلي، الرحلة }
$$

Tema-tema yang diajarkan dari kelas 1 hingga kelas 6 ini jika diperhatikan menyangkut hal hal umum yang ada disekiling peserta didik dan yang dilakukan peserta didik. Tema yang diajarkan pada jenjang sekolah dasar ini diharapkan dapat membantu peserta didik mencapai standar kelulusan: 1) Mengetahui serta memahami bacaan lisan yang berbentuk paparan atau dialog tentang perkenalan dan yang berkaitan dengan lingkungan rumah maupun sekolah, 2) Menyampaikan arti secara lisan yang berbentuk paparan atau dialog tentang perkenalan yang berkaitan dengan lingkungan rumah maupun sekolah, 3) Membacakan dan memahami makna wacana tertulis dalam bentuk paparan atau dialog tentang perkenalan dan yang berkaitan dengan lingkungan rumah maupun sekolah, 4) Menuliskan kata, ungkapan, dan teks fungsional pendek sederhana dengan ejaan dan tanda baca yang tepat sesuai dengan kaidah bahasa Arab yang benar.

b. Kalimat dan Tata Bahasa yang diajarkan 
Pada kelas 1 kalimat belum diajarkan karena yang diajarkan hanya berupa kosakata, kalimat yang diajarkan hanya berupa kalimat sederhana tentang cara berkenalan. memberi kosakata dilakukan melalui pengamatan pada photo/gambar yang sesuai dengan tema lalu memberitahukan makna kosakata dengan langsung memperlihatkan contoh fisik, seperti photo/ gambar, atau benda-benda sekitar, atau alat peraga yang telah disiapkan. Sehingga peserta didik dapat mengerti makna kosakata melalui gambar.

Pada kelas 2 kalimat mulai diajarkan dengan mengenalkan isim isyarah untuk jarak dekat dan jarak jauh serta membedakan penggunaan kata antara Mudzakkar dan

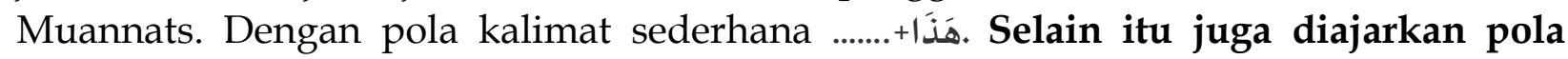
kalimat mempersilahkan minuman/makanan kepada orang lain serta bertanya dengan kata أَ يْن

Pada kelas 3 mulai dikenalkan pola pola kalimat sederhana kepada peserta didik dengan memperjelas kembali masalah isim isyarah untuk jarak dekat dan jarak jauh serta membedakan penggunaan kata antara Mudzakkar dan Muannats. Diajarkan juga ungkapan "lihatlah" dengan pola .......+انظر ال

Pada kelas 4 kalimat sudah mulai kompleks diajarkan tema dengn menggunakan pola kalimat yang meliputi:

$$
\text { الأرقائر (أنا، أنت، أنتِ، هو، هي، نحن) + اسم مفرد مذكر/مؤنث/علم dan اسم إشـارة + اسم مفرد/علم }
$$

(Angka 1-10 terhubung ke kata ganti pria atau wanita tunggal)

Pada kelas 5 tema-tema diajarkan menggunakan pola kalimat yang meliputi مبتدأ + خبر + ظرف أو جار ومجرور أو خبر مقدم + Serta pola kalimat هذا/هذه + ال + اسم + اسم صفة (نعت): مبتدأ + نعت

Pada kelas 6 diajarkan pola kalimat: فعل مضارع/فعل أمر + مفعول باه Selain itu juga menggunakan فعل ماض + فاعل + مفعول بـ. Melihat dari pola kalimat yang diajarkan, maka peneliti menyimpulkan bahwa pola kalimat dan tata bahasa yang diajarkan sudah sangat sesuai dengan tingkat intelektual peserta didik setiap jenjangnya. Ini dibuktikan dari pembelajaran yang dimulai dari yang sederhana hingga kompleks. Pada kelas 1 hingga 3 peserta didik diminta membuat kalimat hanya dengan 1 sampai 3 kata saja, kalimat tersebut juga hanya berupa kalimat ungkapan atau pernyataan. Untuk kelas 4 hingga 6 peserta didik sudah dikenalkan dengan kalimat yang sempurna dengan diajarkannya dialog hingga cerita, sehingga pola kalimat dan tata bahasa juga lebih kompleks. Peserta didik mengenal pola dan tata bahasa juga lebih mudah dan terarah dengan menggunakan dialog bergambar hingga cerita, sesuai dengan tingkat intelektual peserta didik kelas 4 hingga 6 .

c. Kosakata

Kosakata yang diajarkan pada tiap tingkat tentu berbeda jumlahnya, ini dikarenakan kemampuan anak dalam menghafal atau memahami kosakata pun berbeda sesuai dengan usia dan tingkat intelektualnya. Oleh karena itu jumlah dan tingkat kesulitan kosakata/kalimat pun berbeda beda.

Pada kelas 1 jumlah rata rata kosakata yang diajarkan pada tiap tema nya ada 8 hingga 10 kosakata. Kosakata yang diajarkan pun memang kosakata yang ada di sekitar 


\section{MADRASAH}

Jurnal Pendidikan dan Pembelajaran Dasar

p ISSN: 1979-5599 | e ISSN: 2502-194X

Page | 11

peserta didik dengan dilengkapi gambar pada setiap kosakatanya sehingga memudahkan peserta didik memaknainya.

Pada kelas 2 jumlah rata rata kosakata yang diajarkan tetap 8 hingga 10 kosakata. Namun pada kelas 2 pola kalimat sederhana sudah mulai diajarkan. Kata tunjuk jauh dan dekat sudah dikenalkan, sehingga setiap kosakata yang ada mampu dibuat satu kalimat sederhana oleh peserta didik. Pada kelas 2 juga mulai diajarkan menulis kosakata, dengan diawali pembelajaran menyambung huruf huruf hijaiyah menjadi kosakata bahasa Arab.

Pada kelas 3 jumlah rata rata kosakata yang diajarkan pada tiap temanya ada 8 hingga 12 kosakata. Pada kelas 3 kosakata selain mampu dibaca dengan lancar oleh peserta didik, kosakata juga mampu ditulis oleh peserta didik. Selain kosakata benda, dikelas 3 juga diajarkan kosakata ungkapan sederhana seperti lihatlah, marilah, dll. Selain itu kata tunjuk yang telah diajarkan pada kelas 1 dan 2 juga diajarkan kembali dengan lebih jelas.

Pada kelas 4 kosakata yang diajarkan tidak secara jelas perkata tetapi sudah disisipkan/disajikan dalam kalimat atau pun dialog. Sehingga peserta didik harus menemukan kosakata dan memaknai maknanya melalui pemahaman terhadap dialog/cerita. Kosakata yang ada pada kelas 4 jika dicermati kosakatanya sebenarnya sudah diajarkan pada kelas 1 sampai 3. Pada kelas 4 juga diajarkan kosakata ganti, dan penggunaan kata tunjuk.

Pada kelas 5 dan 6 kosakata juga diajarkan dalam bentuk dialog dan cerita. Dengan pola kalimat yang lebih kompleks sehingga kosakata yang harus dipahami peserta didik pun harus banyak juga. Pemaknaan dari tiap cerita/dialog harus dipahami dengan jelas oleh peserta didik, karena peserta didik akan dihadapkan pada tugas tugas yang mengharuskannya memahami kosakata yang ada didalam cerita/dialog.

Kosakata pada kelas 4,5,6 yang telah berbentuk cerita, membuat cara pengajaran guru juga berbeda. Guru mengajarkan kosakata pada kelas 4,5, dan 6 dengan cara membaca dan menterjemahkan bersama dengan seluruh peserta didik. Sehingga proses menterjemahkan cerita/dialog dapat diketahui dan dimengerti semua peserta didik. Peserta didik diminta menulis terjemah dari cerita/dialog di bawah teks pada buku peserta didik.

\section{KESIMPULAN}

Berdasarkan penelitian yang dilakukan maka didapatkan kesimpulanberikut ini;

\section{Proses Pembelajaran Bahasa Arab di MIN 13 Banjar}

a. Pada tahap Perencanaan kegiatan proses belaajar mengajar dilakukan dengan pembuatan silabus dan RPP

b. Pelaksanaan Pembelajaran Bahasa Arab telah sesuai dengan persyaratan pelaksanaan prosespembelajaran yang ditetapkan pada PERMEN PendidikanNasioanal Dan Kebudayaan Republik Indonesia Nomor 65 Tahun 2013 Tentang Standar Proses Pendidikan Dasar Dan Menengah. Pelaksanaan pembelajaran diusahakan sesuai dengan apa yang telah direncanakan sehingga pembelajaran dapat berjalan sistematis dari pendahuluan, kegiatan inti, hingga 
penutup dengan baik sesuai dengan PERMEN Pendidikan Nasional Dan Kebudayaan Republik Indonesia Nomor 65 Tahun 2013.

\section{Ruang Lingkup Pembelajaran Bahasa Arab}

Ruang lingkup pelajaran Bahasa Arab di Madrasah Ibtidaiyah meliputi tema tentang perkenalan, peralatan madrasah, pekerjaan, alamat, keluarga, anggota badan, di rumah, di kebun, di madrasah, di perpustakaan, di kantin, jam, kegiatan sehari hari, pekerjaan, rumah, dan rekreasi. Tema-tema yang diajarkan dari kelas 1 hingga kelas 6 ini jika diperhatikan menyangkut hal-hal umum yang ada di sekitar peserta didik dan dilakukan peserta didik.

Pola kalimat dan tata bahasa pada pelajaran bahasa Arab diajarkan sesuai dengan tingkat intelektual peserta didik. Dimulai dari yang mudah dan sederhana, hingga yang kompleks. Pola kalimat dijelaskan dalam bentuk rumus-rumus sehingga peserta didik mudah memahaminya. Pada kelas 1 hingga 3 peserta didik diminta membuat kalimat hanya dengan 1 sampai 3 kata saja, kalimat tersebut juga hanya berupa kalimat ungkapan atau pernyataan. Untuk kelas 4 hingga 6 peserta didik sudah dikenalkan dengan kalimat yang sempurna dengan diajarkannya dialog hingga cerita, sehingga pola kalimat dan tata bahasa juga lebih kompleks.

Pada kelas 1,2, dan 3 jumlah rata rata kosakata yang diajarkan pada tiap temanya ada 8 hingga 12 kosakata. Kosakata selain mampu dibaca dengan lancar oleh peserta didik, kosakata juga mampu ditulis oleh peserta didik karena peserta didik pada kelas 1 hingga 3 diajarkan menulis Pada kelas 4, 5 dan 6 kosakata juga diajarkan dalam bentuk dialog dan cerita. Sehingga kosakata yang harus dipahami peserta didik pun harus banyak juga.

\section{REFERENSI}

Ali, M. (2007). Guru Dalam Proses BelajarMengajar. Bandung: Sinar BaruAlgensindo.

Anshor, Ahmad Muhtadi. (2009). Pengajaran Bahasa Arab Media dan Metode-Metodenya. Yogyakarta: Teras

Arsyad, Azhar. (2002). Media Pembelajaran. Jakarta: Raja Grafindo Persada

Budiyono. (2003). Metodologi Penelitian Pendidikan. Surakarta: Sebelas Maret University Press.

Hamid, Abdul dan Baharuddin, Uril. (2008). Pembelajaran Bahasa Arab Pendekatan, Metode, Strategi, Materi dan Media. Malang: UIN-Malang Press.

Iskandar. (2009). Metodologi Penelitian Kualitatif. Jakarta: Gaung Persada Press.

Milles, M.B. \& Huberman, A.M. (1992). Qualitative data analysis, a sourcebook of newmethod. Beverly Hills: Sage Publication.

Mulyasa, E. (2006). Kurikulum Yang Disempurnakan. Bandung: Remaja Rosdakarya.

PERMEN Pendidikan Nasioanal Dan Kebudayaan republik Indonesia Nomor 65 Tahun 2013 Tentang Standar Proses Pendidikan Dasar Dan Menengah. Jakarta: Menteri Pendidikan dan Kebudayaan Indonesia.

Sagala, Syaiful. (2003). Konsep dan Makna Pembelajaran. Bandung: Alfabeta

Sardiman, A. M. (2010). Interaksi dan Motivasi Belajar Mengajar. Jakarta: Raja Grafindo Persada.

Suyono dan Hariyanto. (2015). Implementasi Belajar dan Pembelajaran, Bandung: Remaja Rosdakarya 


\section{PANDUAN PENULISAN \\ MADRASAH: JURNAL PENDIDIKAN DAN PEMBELAJARAN DASAR \\ FAKULTAS ILMU TARBIYAH DAN KEGURUAN \\ UNIVERSITAS ISLAM NEGERI MAULANA MALIK IBRAHIM MALANG}

\section{Umum}

1. Karya ilmiah harus asli, belum pernah dipublikasikan di media lain, atau sedang dalam proses review untuk diterbitkan di publikasi lain (melampirkan surat pernyataan).

2. Menggunakan Bahasa Indonesia atau Bahasa Inggris* (*Pastikan penulisan dengan Bahasa Inggris sesuai kaidah yang berlaku, dan disubmit online melalui http://ejournal.uin-malang.ac.id/index.php/madrasah, kami tidak bertanggung jawab jika artikel anda tidak mendapat respon dari reviewer)

3. Menggunakan kertas A4 $(21 \mathrm{~cm} \times 29.7 \mathrm{~cm})$, dengan margin kiri $2.5 \mathrm{~cm}, 2 \mathrm{~cm}$ kanan, $2 \mathrm{~cm}$ bawah, $2 \mathrm{~cm}$ atas.

4. Jumlah paper minimal 7 halaman, maksimal 16 halaman kecuali ada lampiran, toleransi maksimal 20 halaman dengan 1 spasi dan alignment justify.

5. Font yang digunakan Book Antiqua 12 pt dan Sakkal Majalla (Jika ada konten Bahasa Arab) 14 pt.

6. Disarankan menggunakan referensi yang terbaru 10 tahun terakhir, kecuali kitab klasik.

7. Format file menggunakan Mic. Office/open Office (disarankan office 2013/2016_ dengan eksistensi RTF bukan PDF.

\section{Kontent Naskah}

1. Judul maksimal 15 kata, alignment center.

2. Nama penulis tidak menggunakan gelar, mencantumkan institusi, dan email.

3. Abstrak minimal $150 \mathrm{kata}$ dan maksimal $300 \mathrm{kata}$, satu paragraph, tidak terdapat tabel dan gambar.

4. Keywords minimal 3 kata dan maksimal 5 kata, dipisahkan dengan tanda titik koma $(;)$.

5. Sistematika penulisan: Judul, Abstrak, Kata Kunci, Pendahuluan, Metode, Hasil, Pembahasan, Simpulan dan Saran, Pernyataan Terima Kasih (jika ada), Daftar Rujukan. Selain hasil riset, menyesuaikan dengan format penulis.

6. Format Tabel (Bold). Jika terdapat tabel, jarak antara row adalah 1 spasi, pada kategori tabel huruf ditebalkan (bold), dan penulisan sumber setelah tabel terakhir. Jika tabel bersambung ke halaman berikut blok row kategori tabel dengan kemudiak klik layout $=>$ repeat header rows seperti format tabel A.1.

Tabel A.1 Judul Tabel (justify)

(1 spasi)

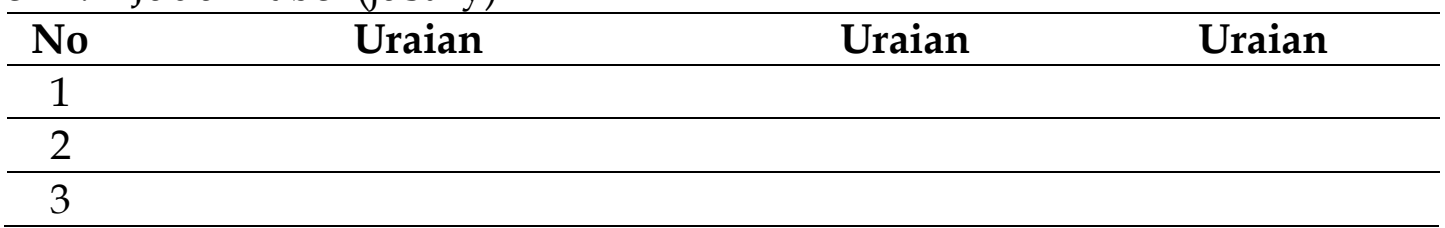

Sumber: 


\section{Format Gambar}

Jika terdapat gambar, grafik, diagram, dan yang serupa gunakan format dan wrap text gambar $=>$ in line with text atau menggunakan fitur text box, untuk kestabilan terhadap perubahan format dan pergesaran. Jarak antara kalimat terakhir dan sesudah gambar adalah 1 spasi. Gambar posisi center (tengah) seperti gambar A.1. (1 spasi)

Gambar A.1 Judul Gambar (center)

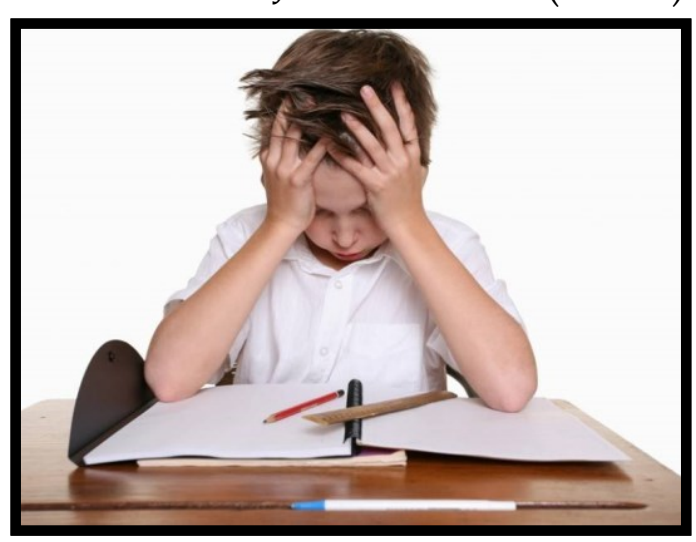

Sumber: (center)

(1 spasi)

\section{Format Numberring}

Pada jurnal Madrasah tidak diperkenankan menggunakan Bullet hanya Numberring, kecuali termasuk dalam penulisan rumus. Numbering menggunakan format Huruf dan Angka. Dimulai dari Huruf kemudian Angka seperti format berikut.

Format Numbering:

A.

1.

2.

a.

b.

1)

2)

a)

b)

B.

C.

9. Daftar Kutipan dan Rujukan menggunakan format APA 6 $^{\text {th }}$ Style Edition. Disarankan menggunakan aplikasi referensi seperti Zotero, Mandeley, Endnote, dan sebagainya.

10. Sebelum mengirim naskah, disarankan untuk melakuken cek typographical dan grammatical errors serta cek plagiat, bisa melalui.

a. Grammarly: www.grammarly.com 
b. Turnitin: http://turnitin.com/

11. Contatc:
a. Website : http://ejournal.uin-malang.ac.id/index.php/madrasah
b. Email : madrasah@uin-malang.ac.id
c. Editor in Chief: M. Irfan Islamy (085390790907)

\section{Author Fees}

This journal charges the following author fees.

Article Submission: 0 (IDR)

Fast-Track Review: 0 (IDR)

Article Publication: 0 (IDR)

Open Donations:

\section{Copyright Notice}

Madrasah: Jurnal Pendidikan dan Pembelajaran Dasar

\section{Privacy Statement}

The names and email addresses entered in this journal site will be used exclusively for the stated purposes of this journal and will not be made available for any other purpose or to any other party. 
UCAPAN TERIMAKASIH

KEPADA PARA REVIEWER, EDITOR, DAN PENULIS ATAS TERBITNYA MADRASAH: JURNAL PENDIDIKAN DAN PEMBELAJARAN DASAR VOLUME 11 NOMOR 1 DESEMBER 2018 